\title{
CHAPTER FOUR
}

\section{THE ANTI-GLOBALIZERS}

\begin{abstract}
Against globalization plays the conviction that this phenomenon has had a very negative impact on the economies and the social tissues of countless countries, developed ones in particular, that, it has represented a zero-sum game in which emerging economies have unilaterally benefited, at the expense of the decline of traditionally rich societies. Above all, there exists the view that globalization identifies itself with greedy elites and corporations from developed economies, which have disproportionally enriched themselves, at the expense of the middle classes and the common citizen, who have carried the burden of disappearing jobs, economic insecurity and a declining life style. These beliefs and sentiments are associated with populist political parties and movements, left-wing politics and with Putinism.
\end{abstract}

\section{The Embattled Fortress}

It was not so at the beginning, when confidence that developed economies could become the natural beneficiaries of globalization prevailed. As Charles Kupchan clearly explains it: "A crisis of governability has beset the Western world. It is no accident that the United States, Europe and Japan are simultaneously experiencing political breakdown; globalization is producing a widening gap between what electorates are asking of their governments and what those governments can deliver...Globalization was supposed to have played to the advantage of liberal societies, which were presumably best suited to capitalize on the fast and fluid global marketplace. But instead, for the better part of two decades, middle-class wages 
in the world's leading democracies have been stagnant and economic inequality is rising sharply. The plight of the West middle class is the consequence primarily of the integration into global markets of billions of low-wage workers from developing economies". ${ }^{1}$

Indeed, by promoting the inclusion into the labor global equation of 1.3 billion Chinese, 1.2 billion Indians or 250 million Indonesians, within the context of a race to the bottom of production costs, Western nations created huge economic and social problems for themselves, while becoming embattled fortresses. Not surprisingly, a June 2008 Harvard Business School study reported that up to 42 percent of American jobs, which represented more than 50 million of them, were vulnerable to being sent offshore. The creative destruction associated with the market economy model, unforeseeable at the beginning, brought with it a lot of creation for emerging economies, and substantial destruction to developed ones.

The leverage of emerging economies significantly increased. In addition to their preponderance in commodities and new markets, they have gotten a substantial hold on manufacturing industries, brainwork, technology and cash, whereas Western economies have just cornered themselves. In Kishore Mahbubani's words, "The rest of the world, paradoxically, is more ready than Americans for a globalization that Americans themselves are creating". ${ }^{2}$

\section{Slicing the Salami}

Like slicing a salami, this process went through several stages. Western economies began by offshoring their blue-collar jobs to developing economies, which was tantamount to transferring part of their industrial might to those economies. Since 2001, nearly 60,000 manufacturing plants left the US and boarded up in emerging economies. ${ }^{3}$ Around 450 of the largest

\footnotetext{
${ }^{1}$ Charles A Kupchan, "Refunding good governance", The New York Times, 19 December 2011.

${ }^{2}$ Kishore Mahbubani, "The seesaw of power: A conversation with Joseph Nye, Dambisa Moyo and Kisshore Mahbubani”, International Herald Tribune Magazine, 24 June 2011. ${ }^{3}$ Bernie Sanders, Our Revolution: A Future to Believe In (London: Profile Books, 2017), p. 280.
} 
500 multinationals invested in China. ${ }^{4}$ Moreover, a fundamental part of China's trade with the world, since the beginning of the millennium, stemmed from foreign firms producing in China in order to sell their products somewhere else. More than 50 percent of China's exports were paid for by foreign firms, and were the result of foreign investments in China. ${ }^{5}$

Subsequently, Western economies offshored their white-collar jobs to developing economies. This implied relying on the strength of foreign brains, at the expense of making their own brains increasingly redundant. A 2006 study by the consulting firm Booz Allen Hamilton stated that white-collar offshoring included high-end work, which had traditionally been considered "core" to the business, such as chip design, financial and legal research, clinical trial management, book editing and so forth. The convergence of lower costs and the huge pool of available talent in emerging economies, such as India, led in that direction and implied the risk of tens of millions of jobs migrating from the West. Moreover, it was argued that high-wage jobs, performed by highly educated employees in the United States were, if anything, more offshorable than other service jobs. ${ }^{6}$

In the next phase, Western economies massively transferred their technology to China. This was done in two ways. First, it became a mean of gaining access to that country's gigantic market. Second, the technology was sold directly to Chinese firms. General Electric was a good example of the former, as it handed over its most sophisticated aeronautical electronic technology, in order to benefit from the Chinese aeronautical market, one expected to generate 400 billion dollars in sales during the next 20 years. The sale of technology to China, by American or European companies, frequently implied selling the companies that were producing it. This went from Volvo to MG and from IBM's Personal Computers

\footnotetext{
${ }^{4}$ Xulio Ríos, "Crédito y descrédito en América Latina", Jiexi Zhonguuo: Análisis y Pensamiento Iberoaméricano sobre China, Número 2, Primer Trimestre 2012, pp. 23-24. ${ }^{5}$ Zachary Karabell, op. cit., pp. 156-157.

${ }^{6}$ Alan S Blinder "Offshoring: The next industrial revolution", Foreign Affairs, 2006, Volume 85, pp. 113-128; Alan S Blinder and Alan B Krueger, "Alternative measures of offshorability", National Bureau of Economic Research, Working Paper 15287 (August 2009), http://www.nber.org/papers/w15287. Accessed 25 July 2015; Arianna Huffington, Third World America (New York: Crown Publishers, 2010).
} 
Division and France's Thompson to numerous medium-sized Silicon Valley corporations.

\section{From Job-Killing Offshoring to Job-Killing Automation}

In the process, as it was to be expected, Western corporations obtained disproportionate profit margins. According to Ohio-based hedge fund manager John Hussman, in 2011, profit margins by US companies were 50 percent above historical levels. ${ }^{7}$ However, when faced with the competition of good quality but lower-priced foreign products - resulting from the combination of offshoring and technology transfer - Western corporations responded by multiplying job-killing technologies home.

As Rana Foroohar remarked in 2011: "That so many of the jobs we now create are low end, underscores a growing debate over technology and its role. Many of the jobs that have disappeared from the U.S. economy have done so not only because they were outsourced but also because they are now done by computers or robots". ${ }^{8}$ Not surprisingly, a wellknown 2013 Oxford University report predicted that up to 47 percent of existing employment in the United States would disappear within the next one to two decades as a consequence of digital technology. ${ }^{9}$

On the same note, Edward Luce wrote, also in 2011: "The jobs that are currently being created in the United States are those relatively lowskilled and low-paid that cannot be replaced either by offshoring or jobkilling technologies. In short, the middle-skilled jobs that once formed the ballast of the world's wealthiest middle class are disappearing...a growing share of whatever job the economy is still managing to create is in the least productive areas. Of the five occupations forecast by the Bureau of Labour Statistics to be the fastest growing between now and 2018, none requires a degree. These are registered nurses, 'home health aides',

\footnotetext{
${ }^{7}$ Andy Mukherjee, "Work and wages versus wealth and welfare", The Straits Times, 17 November 2011.

${ }^{8}$ Rana Foroohar, "What ever happened to upward mobility?", Time, 14 November 2011. ${ }^{9}$ Carl Benedikt Frey and Michael E Osborne, "The future of employment: How susceptible are jobs to computerization", Oxford University, 17 September 2013. http://www. oxfordmartin.ox.ac.uk/downloads/academic/The_Future_of_Employment.pdf. Accessed 25 July 2016.
} 
customer services representatives, food preparation workers and 'personal home care aides'...If there is an explanation as to why middle-class incomes have stagnated in the past generation, this is it: Whatever jobs the US is able to create are in the least efficient sectors - the types that neither computers nor China have yet found a way of eliminating." 10

Not surprisingly, corporate profits today are at their highest levels, as a percentage of GDP, in more than 85 years. At the same time, wages and salaries for American workers have reached one of their lowest points in more than 60 years. ${ }^{11}$

\section{Turning the Rich, Richer}

While corporations have been suppressing jobs at home, they have simultaneously been arguing against tax increases in the United States. Labeling those increases as "class warfare", they have managed to massively evade taxes at home while lobbying for tax benefits. The results have been impressive. In 2015, IBM made nearly US\$6 billion in profits in the US and yet, instead of paying federal taxes, it got 321 million in tax refund. Also, in 2015, Xerox made US\$537 million in profits but received 23 million in tax refund. The same year, American Airlines earned US $\$ 4.6$ billion, receiving nearly 3 billion from the Internal Revenue Service. Citigroup had earnings of US\$6.6 billion in 2013 and yet received a tax refund of 260 million. From 2010 to 2012, Pfizer made US $\$ 43$ billion in profits worldwide, but received 2.2 billion from the IRS. And the list goes on. ${ }^{12}$

At the same time, American corporations have invested vastly in buybacks of their own stocks, instead of creating new jobs. The principle behind this awkward use of funds is simple. With fewer shares in the market, earnings per share tend to rise and, by investing in their own stocks, companies benefit from short-term jump in stock prices. This, of course, reflects well in their quarterly reports. Needless to say is that, as

\footnotetext{
${ }^{10}$ Edward Luce, "Is America working?" Financial Times, 11 December 2011.

${ }^{11}$ Senator Cory Booker, "The American dream deferred", Brookings, June 2018, https:// www.brookings.edu/essay/senator-booker-american-dream-deferred/?. Accessed 30 June 2018.

${ }^{12}$ Bernie Sanders, op. cit., pp. 275-276.
} 
top executives are normally shareholders of the companies under their control, they benefit from these short-term jumps. This also helps senior management collect millions in cash and stock incentive payments, by meeting earnings-per-share goals.

In 2011, Nelson D. Schwartz wrote: "After diving in the wake of the financial crisis, buybacks have made a remarkable comeback in recent years, with $\$ 445$ billion authorized this year, the most since 2007, when repurchases peaked at $\$ 914$ billion". ${ }^{13}$ As Cory Booker, Democrat Senator from New Jersey, pointed out: between 2003 and 2012, companies on the S\&P 500 dedicated 91 percent of their total net earnings to stock buybacks and corporate dividends. That left just nine percent for the rest. The rest not only means new plants and developments, but also payment and investments in the workforce, including expanded training. ${ }^{14}$

Senator Booker also mentions how companies are relying on a range of practices to avoid workers from moving into better pay employment. In his words: "One of the core issues that has arisen in recent years in 'monopsony power', whereby one or a handful of employers have become so dominant in their market or their region that they can exercise enormous control not just over their worker's wages and their terms of employment, but even over where they can work. Corporations are increasingly exercising monopsony power through purposeful practices specifically aimed at weakening worker mobility and keeping a lid on wages. Workers all across the country, and in a wide range of occupations.... are being held back under the threat of restrictive covenants that limit their ability to change jobs and get ahead". ${ }^{15}$

Monopsony power materializes through instruments like the so-called "non-compete" clauses and "no-poaching agreements". On the one hand, non-compete clauses are agreements between employers and employees that were originally intended to protect trade secrets and hold on to workers who had highly technical training. But now, this clause is being used

\footnotetext{
${ }^{13}$ Nelson D Schwartz, "In U.S., stock buybacks win out over jobs", International Herald Tribune, 23 November 2011.

${ }^{14}$ Senator Cory Booker, op. cit.

${ }^{15}$ Ibid.
} 
not to protect trade secrets and retain highly qualified employees, but as a means to keep low-wage workers under their employer's total control.

Not only are they contractually forbidden to move into higher paid jobs in similar industries or activities, but being at the mercy of their employers, they cannot even expect to obtain better wages within the same company. As mentioned by Senator Booker, sometimes workers sign noncompete clauses unknowingly, while others they do it for lack of options.

No-poaching agreements, on the other hand, prohibit the franchisees of a large company to recruit and hire away another's workers. This prevents employees from finding higher paying jobs within the same chain. As a result, the employees' leverage to negotiate for a raise is reduced to a minimum. In 2016, 58 percent of the US larger franchisors had in place no-poaching agreements.

\section{The 2008 Financial Crisis}

The result of this dramatic process has been a gigantic economic polarization in the United States. And on top of it all, this polarization was compounded by an additional event: the worst financial crisis since the Great Depression of 1929. The prevailing laissez faire environment was, again, the reason behind the 2008 financial crisis. Lax financial regulations allowed indeed for all kinds and shapes of excesses to be committed.

This course got on a fast track with the repeal of the Glass-Steagall Law in 1999. Its abolition threw down the fence that had so far prevented commercial banks into entering the investment banking business, and thus promoted their off-balance-sheet activities. Nonetheless, the major problems did not result from the excesses committed by deregulated commercial banks, but from those of other institutions which never been subjected to regulations: the so-called shadow banks.

The shadow banking system was constituted by a group of institutions (hedge funds firms, private equity firms, among others), which acted as banks without being so. They were involved in high-risk financial instruments such as hedge funds, auction rates, repo-tripartite, bonds with options, structured investment vehicles and the like. It is hardly surprising that without any kind of supervision, shadow banks simply went wild. Authoritative figures like Brooksley Brown, head of the Commodity 
Futures Trading Commission, had issued loud warnings about the consequences of failing to regulate the financial derivatives in the late 1990s. However, the Commodity Futures Modernization Act, passed by Congress in December 2000, under the auspices of Treasury Secretary Larry Summers and Federal Reserve Bank Chairman Alan Greenspan, banned any attempt to regulate derivatives and new investment instruments. ${ }^{16}$

This environment was perfectly symbolized by a 2003 photo session in which representatives of different federal regulatory bodies cut piles of regulations with power saws and pincers. According to the prevailing dogma of the day, markets were perfectly able to self-regulate. In the words of Dambisa Moyo: "In the US, Chairman Greenspan, as a convert and proselytizer for self-regulation, oversaw the rise of what came to be termed the shadow banking system. This was the network of hedge funds, private equity firms and off-balance-sheet entities that where outside the purview of the Fed....Such was the byzantine nature of the derivative complex that no one actually appreciated the size and indeed the whereabouts of this labyrinth of debt". ${ }^{17}$

Such extremes were much helped by the underestimation of risk that came from easy money. In C. Fred Bergsten words: "These huge inflows of foreign capital, however, turned out to be an important cause of the current economic crisis, because they contributed to the low interest rates, excessive liquidity, and loose monetary policies that brought the overleveraging and underpricing of risk...". ${ }^{18}$

Indeed, after having promoted China's trade surplus, through the offshoring of blue-collar jobs, the United States let China finance its own spending binge. As Fareed Zakaria pointed out: "Through their accumulation of massive quantities of American debt, the Chinese ended up subsidizing the behavior that caused it - American consumption. They financed our spending binge and built up a vast hoard of dollars IOUs". ${ }^{19}$ China's lending was not only responsible for the United States living beyond their means, but also created the cheap money that encouraged financial excesses in that country.

\footnotetext{
${ }^{16}$ Edward Luce, op. cit.

${ }^{17}$ Dambisa Moyo, How the West was Lost (London: Allen Lane, 2011), pp. 66-67.

${ }^{18}$ Fred C Bergsten, "The dollar and the deficits", Foreign Affairs, 2009, Volume 88, p. 24.

${ }^{19}$ Fareed Zakaria, The Post-American World and the Rise of the Rest (London: Penguin Books, 2009), p. xx.
} 


\section{The Mortgage Crisis Carnage}

This was the underlying reason why the mortgage market in the United States was so full of cash that it became possible to obtain a 100 percent mortgage without an income, a job or even assets. As such, this became the spark that unleashed the American financial fire.

The immediate cause of it, though, were the so-called "securizations", in which different kinds of mortgages were bundled together, repackaged and converted into securities that went into the financial market. Bad mortgages were prevalent due to two main considerations. Firstly, because the larger the mortgage was, the larger the fee that the banks, as mortgage originators, got paid. Secondly, because lending banks did not bear the risk if the borrower did not repay. Thanks to securization, irresponsible lending became the norm.

The toxic securities therein derived were subsequently sold as highly trustable financial products. When this distorted system imploded, as it was bound to do sooner or later, countless American middle-class citizens not only saw their pensions evaporate, but millions of middle-class families who were led to believe that they could become homeowners, suffered foreclosures and evictions.

As Joseph Stiglitiz explained, the banks' influence dominated almost every decision the government made within the subsequent rescue efforts. Not only did the banks and the U.S. Treasury have a common interest in not writing down the principal of the mortgages, as that would have forced the banks to recognize the loss, but the banks actually objected to homeowners under stress borrowing at low interest rates as they themselves were doing from the Federal Reserve. In sum, both the Bush and Obama administrations followed the same course of action: concentrating their efforts on the rescue of the banks, and not the indebted homeowners. ${ }^{20}$ The result, as Elizabeth Warren reported, was that more than 120,000 families were filing for bankruptcy every month. ${ }^{21}$

Atif Mian and Amir Sufi, economists at Princeton and the University of Chicago, have argued that the government's efforts should have gone to families and the collapsed housing market, rather than the financial sector.

\footnotetext{
${ }^{20}$ Joseph Stiglitz, Freefall: Free Markets and the Sinking of the Global Economy (London: Penguin Books, 2015).

${ }^{21}$ Alfredo Toro Hardy, op. cit., p. 81.
} 
In their view, the core of the problem should have been the relationship existing between indebtedness, falling consumption and high unemployment, and not financial loses. Foreclosures, according to their argument, drove down housing prices and generated a vicious cycle. More people underwater, wallowing in debt and unwilling to spend money meant higher unemployment, which, in turn, led to further foreclosures. This not only affected people and communities, but the real economy as well. As they concluded, there was nothing healing in this perverse cycle induced by the government's distorted priorities. ${ }^{22}$

\section{The Numbers Behind Social Polarization}

How to be surprised, then, by the numbers revealed behind this social polarization? Since the end of the 1970s, the earnings of the upper 1 percent have increased by 156 percent, and that of the 0.1 percent at the top by 362 percent, while the 40 percent at the bottom owes more than it owns. ${ }^{23}$ Moreover, the top 1 percent owns almost as much wealth as the bottom 90 percent. The salary of the majority of the working population, meanwhile, has remained stagnant since the end of the 1970s. ${ }^{24}$

But the numbers keep uncovering an alarming divide. Billionaires in the US grew tenfold between 2000 and 2015. In 2000, the US had 51 billionaires with a combined net worth of US $\$ 480$ billion. In 2015 , the country had a record-breaking 540 billionaires with a combined net worth of US $\$ 2.4$ trillion. Moreover, the 20 wealthiest Americans own more wealth than the bottom 150 million people..$^{25}$

Between 2002 and 2007, the 1 percent at the top obtained two-thirds of the gains resulting from the economic growth experienced during that period. However, the richest 0.1 percent got the two-thirds of that 1 percent received. In 2010, the six heirs of Sam Walton, Walmart's founder,

\footnotetext{
${ }^{22}$ Atif Mian and Amir Sufi, House of Debt (Chicago: The University of Chicago Press, 2014). ${ }^{23}$ Alvin Powell, "The cost of inequality: When a fair shake isn't", Harvard Gazzete, 1 February 2016, https://news.harvard.edu/gazette/story/2016/02/the-costs-of-inequalitywhen-a-fair-shake-isnt/. Accessed 27 January 2017.

${ }^{24}$ Nicholas Kristof, “Occupy Wall Street' and inequality", New York Times, 15 October 2011; Bernie Sanders, op. cit., p. 207.

${ }^{25}$ Bernie Sanders, op. cit., pp. 207-208.
} 
had a combined wealth superior to the 40 percent at the bottom of America's society. Meanwhile, in 2009, 80 percent of the country's population had shown a net decrease of its patrimony in relation to $1983 .{ }^{26}$

As a result of this economic polarization, only two types of jobs have increased in numbers in the last few years. On the one hand, Wall Street financiers, Silicon Valley entrepreneurs, corporate managers, doctoral engineers and physicists and the like, are doing extremely well. On the other hand, there are the low-end services undertaken by nurses, domestic aides, food preparers, janitors, auto repair workers, nutritionists and such. Between both types of jobs there is a gap labeled as the missing middle. A middle of more than 100 million people who, according to Roger Cohen, in 2011, were falling in a downward spiral close to or below the poverty line. ${ }^{27}$

Bernie Sanders says that the median income in the US, i.e., the amount of money of the household right in the middle, is almost US\$1,400 less than it was in 1999, after adjusting for inflation. At the same time, the real median income of full-time male workers is US\$2,144 less than it was 43 years ago. Over the past decade, 81 percent of US households saw "flat" or "failing" incomes. ${ }^{28}$ As Martin Ford mentions, income inequality in the US has soared to levels not seen since 1929. ${ }^{29}$

Martin Ford also remarks on how economic polarization translates into deeply unequal consumption patterns. In his words: "The top 5 percent of the households are currently responsible for nearly 40 percent of spending, and that trend towards increased concentration at the top seems almost certain to continue". ${ }^{30}$

\section{The Regional Divide}

It is worth noting that this economic polarization is directly linked to a regional divide as fundamental differences exist between large coastal

\footnotetext{
${ }^{26}$ Erik Brynjolfsson and Andrew McAffe, The Second Machine Age (New York: W.W. Norton \& Company, 2014).

${ }^{27}$ Roger Cohen, "Decline and fall”, International Herald Tribune, 22 November 2011.

${ }^{28}$ Bernie Sanders, op. cit., pp. 210-211.

${ }^{29}$ Martin Ford, Rise of the Robots: Technology and the Threat of a Jobless Future (Electronic book, New York: Basic Books, 2015), p. 91/6743.

${ }^{30}$ Ibid, p. $176 / 6743$.
} 
cities, essentially global cities, and inland United States. In Paul Krugman's words: "On the economic side, some parts of America, mainly big coastal cities, have been getting much richer, but other parts have been left behind (...) In the most part I'm in agreement with Berkeley's Enrico Moretti, whose 2012 book The New Geography of Jobs, is must reading for anyone trying to understand the state of America. Moretti argues that structural changes in the economy have favored industries that employ highly educated workers - and that these industries do best in locations where there are a lot of these workers. As a result, these regions are experiencing a virtuous circle of growth: Their knowledge-intensive industries prosper, drawing even more educated workers, which reinforces their advantage. And at the same time, regions that started with a poorly educated work force are in a downward spiral, both because they're stuck in the wrong industries and because they're experiencing what amounts to brain drain". ${ }^{31}$

On the one hand, then, there are busy, favored coastal cities; on the other hand, the left-behind areas of the US, which are beginning to show alarming signs of social decay. A Harvard University analysis of 1.4 billion Internal Revenue Service records on income and life expectancy, showed amazing differences in life expectancy between the richest and the poorest. People living in wealthy cities such as New York City, Boston, Los Angeles or San Francisco have life expectancies significantly longer that those in poorer inland regions. Life expectancy in the latter is now equal to places like Sudan or Pakistan. When data was laid over maps of the United States, low life expectancy concentrated not in the Deep South, but across the Midwest Rust Belt. People in New York or San Francisco live longer than in the industrial Midwest. Among men, the gap is around 15 years. $^{32}$

Paul Krugman gets into further detail as to the reason of this life expectancy gap between big coastal cities and the Midwest Rust Belt. In his words: "To be sure, social collapse in the white working class is a deadly

\footnotetext{
${ }^{31}$ Paul Krugman, "What's the matter with Trumpland?", The New York Times, 2 April 2018.

${ }^{32}$ Peter Reuell, "For life expectancy, money matters", The Harvard Gazette, 11 April 2016, https://news.harvard.edu/gazette/story/2016/04/for-life-expectancy-money-matters/. Accessed 27 January 2017.
} 
serious issue. Literally. Last fall, the economists Anne Case and Agnus Deaton attracted widespread attention with a paper showing that mortality among middle-aged white Americans, which had been declining for generations, started rising circa 2000. This rising death rate mainly reflected suicide, alcohol and overdoses of drugs, notably prescriptions opioids... And other signs of social unraveling, from deteriorating health to growing isolation, are also on the rise among American whites. Something is going seriously wrong in the heartland". ${ }^{33}$

The mind-blowing extent of this economic inequality is described by Martin Ford in the following terms: "While inequality has been increasing in nearly all industrialized countries the United States remains a clear outlier. According to the Central Intelligence Agency's analysis, income inequality in America is roughly on par with that of the Philippines and significantly exceeds that of Egypt, Yemen and Tunisia". ${ }^{34}$

The causes of this social inequality are many. Beyond those mentioned in previous pages, others like significant tax reduction for the wealthiest, the decreasing power of unions, social divestment, austerity policies derived from the financial crisis, plus a huge public debt, are also in line. The majority of these causes are closely related to the market economy policies that date back to the Reagan Administration. However, there is an important additional element that has to be put in the mix: the flexibilization of campaign financing rules by the Supreme Court.

\section{The Koch Brothers}

The conjunction between the disappearance of donation limits and the possibility to shield the identity of donors has exponentially increased campaign contributions and, with it, their political leverage. As a result, politics and big business have become intermingled as never before. As if Iron Triangles, lobbies and Political Action Committees were not enough to influence the decision-making process on behalf of big money, Supreme Court's "Citizens United" decision of 2010 consolidated this symbiotic

\footnotetext{
${ }^{33}$ Paul Krugman, "Republican elite's reign of disdain", The New York Times, 18 March 2016.

${ }^{34}$ Martin Ford, op. cit., p. 868/6743.
} 
relation. Thanks to the so-called "independent expenditures", the wealthiest people and the largest corporations of the United States can now spend unlimited sums of money on their preferred candidates.

As a result of this, the Republican Party came to be controlled by the Koch brothers (the second wealthiest family in the US), and a group of no fewer than 18 billionaires acting under the stewardship of the Kochs. The Grand Old Party was forced to bow low before a conjunction of oil, banking, defense, chemical, pharmaceutical and brewing interests, and to their extreme right agenda.

Their agenda includes, among other things, the abolition of Medicare and Medicaid programs; the abolition of any compulsory insurance or taxsupported plan to provide health services; the repeal of the Social Security system; the abolition of the governmental Postal Service; the repeal of minimum wage laws; the elimination of governmental ownership, operation, regulation and subsidy of schools and colleges; the end of compulsory education laws; the privatization of the public roads and the national highway system and all government welfare and aid to the poor programs. In other words, a political agenda that clearly reflects their patrimonial interests. ${ }^{35}$

In Jane Meyer terms: "The Kochs were not alone. As they sought ways to steer American politics hard to the right...they got valuable reinforcement from a small cadre of like-minded wealthy conservative families who were harnessing their own corporate fortunes toward the same end...But their goal was patently political: to undo not just Lyndon Johnson's Great Society and Franklin Roosevelt's New Deal but Teddy Roosevelt's Progressive Era, too". ${ }^{36}$ John J. Miller, quoted by Jane Meyer, adds: "What they started is the most potent machinery ever assembled in a democracy to promote a set of beliefs and to control the reins of government." 37

Noreena Hertz clearly explains the implications herein involved, when she says: "Wherever we look, corporations are capturing the responsibilities of governments...Governments, by not even recognizing this capture, are putting at risk the implicit contract that exists between them

\footnotetext{
${ }^{35}$ Jane Meyer, Dark Money: How a Secretive Group of Billionaires is Trying to Buy Political Control in he US (Electronic book, New York: Doubleday, 2016).

${ }^{36}$ Ibid, p. 1104/9091.

${ }^{37}$ Ibid, p. 1774/9091.
} 
and the citizens, and which represents the essence of every democratic society". ${ }^{38}$ The breakdown of this social contract has profound political implications, as citizens feel increasingly estranged from the political system.

How to be surprised by the fact that already in 2008, 80 percent of Americans surveyed told the Program on International Policy Attitudes that they believed that "a few big interests, looking for themselves" controlled the government. ${ }^{39}$ Confidence in the political system has plummeted as a result of this situation. Trust in Congress, indeed, dropped from 42 percent in 1973 to just 8 percent in 2015, an approval rating lower than any other institution, including banks or big business. ${ }^{40}$ The significance of this is enormous, as the connivance of the political class with banks and big business, seems to be considered even more reprehensible than the greediness and selfishness of the latter.

\section{The European Union Conundrum}

Many of the aforementioned elements are also reproduced within the European Union, especially those related to their corporations' offshoring of countless jobs to China and other emerging economies, and to job killing technologies in response to the foreign competition that they helped to nurture. As the McKinsey Global Institute reports, in the United States and in the 15 core European Union countries, otherwise known as EU-15, there are 285 million adults who are not in the labor force. ${ }^{41}$ However, it must be said, the extreme social inequality that characterizes the US, is mainly absent from Europe.

Lucas Chancel provides the right context of the European social divide when saying: "Inequality is on the rise across the world, but it's not increasing everywhere at the same pace. In many ways Europe stands out as a positive exception. Despite the criticism thrown out at the EU, it is a global

\footnotetext{
${ }^{38}$ Noreena Hertz, The Silent Takeover (London: William Heinemann, 2011), p. 11.

${ }^{39}$ Arianna Huffington, op. cit., p. 129.

${ }^{40}$ Stephen D King, op. cit., p. 21.

${ }^{41}$ James Manyika, "Technology, jobs, and the future of work”, McKinsey Global Institute, Executive Briefing, May 2017, https://www.mckinsey.com/featured-insights/employmentand-growth/technology-jobs-and-the-future-of-work. Accessed 23 April 2018.
} 
leader in preserving a degree of fairness in the social fabric...Today, the top $1 \%$ in Europe take $12 \%$ of the income... while the bottom $50 \%$ have $22 \% \ldots$ Put bluntly, the EU has resisted the notion of turning its market economy into a market society. It has partly rejected the thinking of Ronald Reagan and Margaret Thatcher, in which market forces, in the absence of any regulation, provide the best of all worlds in areas such as education, health and wages. There are large differences within Europe, though: the UK and Ireland have followed the American path more closely than continental Europe...That said, social healthcare systems in most European countries still guarantee universal protection for all - hardly the case in the US. Many of those countries offer free access to university...Labour markets are also more favourable in Europe than in the US, where the minimum wage has fallen by a third in real terms since the 1970s (in France it has risen fourfold). In Sweden and Germany, trade unions are represented in corporate governance bodies, taking part in strategic decision-making". ${ }^{42}$

In spite of all this, the European Union still presents two serious problems: undemocratic decision-making at the top and the application of austerity measures all around Europe, particularly harsh in peripheral nations, where there has been a burdensome debt crisis. Both these problems have alienated a large part of its population.

European institutions, governments and elites have clearly underestimated the popular will. Under this premise, several of its governments, and particularly the British one, ignored the overwhelming rejection of its population, expressed both in the polls and in the streets, in relation to the Iraq invasion in 2003. A couple of years later, in 2005, and as a result of the widespread dissatisfaction with the EU's structure by its member states, the federation's leadership presented the draft of a new Constitution for approval purposes. Such approval was to come by direct consultation of its populations, by way of referendum. However, that same year, 54.9 percent of French voters and 61.5 percent of Dutch voters rejected the proposed Constitution. At that point, the European Council decided to relabel the constitutional proposal as a Treaty, so that it would not have to be subjected to popular ratification.

\footnotetext{
${ }^{42}$ Lucas Chancel, "The fairest of them all: Why Europe beats the US on equality", The Guardian, 24 January 2018.
} 
This bureaucratic manipulation translated into the Lisbon Treaty, approved in October 2007. The reason for this relabeling was clear. In order to pass a treaty, only the affirmative will of the governments and the ratification of the parliaments were needed. However, for its own constitutional reasons, the Irish government decided to submit the Treaty of Lisbon to a popular referendum. This meant going back to round one.

Again, popular consultation provided the same results that it had given in France and in the Netherlands in 2005. In 2008, indeed, the treaty was rejected by 53.4 percent of the Irish voters. Other EU governments met this rejection by putting an overwhelming pressure upon the Irish one to hold another referendum. As a consequence, a new direct consultation of the Irish citizens was held in 2009, this time with positive results. The logic that worked in the end was this: keep the citizens voting until they vote right. This underestimation of the people's will is tantamount to a clear democratic deficit. As a result, both EU institutions and national governments have become the target of popular anger.

The second problem, originating in the application of austerity policies within the block is dual in nature: it relates to the management of the debt crisis in highly indebted Eurozone counties, and is the result of the EU's decision to cut national deficits in all of its 27 member states.

\section{The Austerity Nightmare}

The management of the debt crisis was, of the two, the bigger problem and was directly linked to the complexity of the so-called Eurozone, that is, the 19 nations with varying degrees of economic developments where the $€$ is the official currency. To put things in context in relation to this crisis, we have to go back to the early 2000s, when several of its economies, the so-called PIIGS (Portugal, Italy, Ireland, Greece and Spain), ran large trade deficits.

Germany and other EU countries, which enjoyed trade surpluses, helped these indebted economies through loans and bond purchases. However, when the financial crisis of 2008 hit hard and credit dried up internationally, creditors began collecting their loans. Behind this situation, there were several reasons worth taking note of. 
The first was projecting a wrong impression regarding the nature of the sovereign debt amid the members of the Eurozone. According to Gordon Brown: "Financial markets assumed from the outset that the European Central Bank was ready to accept at its discount window the sovereign debt of all member countries on equal terms, thus fostering the impression that all euro sovereign debt was of equal quality". ${ }^{43}$

It should have been obvious, though, that if both the German and the Greek debts were seen on an equal footing, the result would be low interest rates as well as happy borrowing by the weaker economies of the zone. For the latter, to borrow in the same conditions as its core members became a temptation difficult to resist.

The second reason was the macroeconomic straitjacket that the $€$ imposed upon its member countries, who were forbidden to devaluate. Again, in Gordon Brown's terms: "It was a risk...because Europe's countries did not appear to have the flexibility necessary to adjust their economies to crises". ${ }^{44}$ Indeed, countries like Japan or the United States, which run large deficits, have been able to finance them by simply printing more of their currencies. Not being able to devaluate takes away all room for maneuver from indebted countries, leaving austerity measures as the only alternative.

The third reason was lurking in the European Central Bank (ECB) statues, which limited its role. Instead of enjoying an ample mandate to deal with the different problems that the $€$ might have experienced, its mandate focused primarily on keeping inflation under control. The $€$ became, thus, the only international currency that did not have a lender of last resort.

As a result, the only institution that could have acted unilaterally and decisively to avert the crisis, by buying the sovereign bonds of the affected economies, was not able to do so. As John Quiggin explained: "Unlike any previous central banks in history, the bank has disclaimed any responsibility for the European financial system it effectively controls, or even for the viability of the euro as a currency. Instead, it has focused entirely on the

\footnotetext{
${ }^{43}$ Gordon Brown, op. cit., pp. 183-184.

${ }^{44}$ Ibid, p. 186.
} 
formal objective of keeping inflation rates to a 2 percent target" ${ }^{45}$ It must be added, nonetheless, that under the increasing pressure of the crisis, the institutional boundaries of the bank were subsequently expanded.

Indebted countries could not dig themselves out of a fiscal hole through devaluation, unless they abandoned the Eurozone altogether. However, that looked like jumping off a cliff. The only available option left to them was to convince the creditor countries to forgive part of the debt, which proved easier said than done as Angela Merkel's Germany loudly opposed any bailout. In this, Berlin was followed by other Northern European economies.

\section{Merkel's Harshness}

Merkel's harshness stands awkwardly out against the treatment that her own country got in 1953. In a historical meeting in London, the 20 countries that were owed by the Federal Republic of Germany decided to erase from their credit books more than half its debt. Had this half not been forgiven, would the Federal Republic have evolved differently, at a different pace maybe? We are entering here into the realm of counterfactual history, and this is not the purpose of the book. What is certainly verifiable is that Hitler's emergence into power was directly linked to the social costs associated with the World War I reparation debt, and this was obviously taken into account in 1953.

The fact remains, however, that passing over the objections of the majority of EU's member countries and the IMF itself, Merkel's Germany was instrumental in imposing upon Athens one of the most painful structural packages in recent history. The "Troika" of the European Commission, ECB and IMF, was very much the visible face of the negotiations with Greece and later with Spain, imposing draconian austerity measures upon them both. However, the leading force behind the "Troika" was Germany.

Two of the most important economists of our day, Nobel Laureates Joseph Stiglitz and Pal Krugman, reacted against such senseless austerity measures, their multiplier economic effect and their social and political

\footnotetext{
${ }^{45}$ John Quiggin, "Enabling the euro crisis", International Herald Tribune, 11 October 2011.
} 
implications. According to Stiglitz: “... austerity has been an unmitigated disaster, which has become increasingly apparent as European Union economies once again face stagnation, if not a triple-dip recession, with unemployment persisting at record highs and per capita real (inflationadjusted) GDP in many countries remaining below recession levels. In even the best-performing economies such as Germany, growth since the 2008 crisis has been so slow that, in any other circumstance, it would be rated as dismal. The most afflicted countries are in depression. There is no other word to describe an economy like that of Spain or Greece, where nearly one in four people - and more than $50 \%$ of young people - cannot find work...Meanwhile, Germany is forcing other countries to follow policies that are weakening their economies — and their democracies". ${ }^{46}$

Paul Krugman, on his side, expressed: “...Germany is demanding that Greece keep trying to pay its debts in full by imposing incredibly harsh austerity...Chaos in Greece could fuel the sinister political forces that have been gaining influence as Europe's Second Great Depression goes on and on...Looking forward, however, how much can Greece take? Clearly it can't pay the debt in full; that's obvious to anyone who has done the math. Unfortunately, German politicians have never explained the math to their constituents. Instead, they've taken the lazy path: moralizing about the irresponsibility of the borrowers, declaring that debts must and will be paid in full, playing into stereotypes about shiftless southern Europeans". ${ }^{47}$

But of course, austerity policies were also harsh in the other highly indebted countries, namely, Portugal, Ireland, Italy and Spain. Nonetheless, as mentioned above, there was another dimension to austerity that came from the strict limits imposed upon the EU members' deficits. These were to be reduced, in all of its 27 member states, to a maximum of 3 percent by the financial year 2014-2015.

\section{EU Austerity Policies}

This, of course, imposed variable degrees of sacrifice upon the different countries of the union. The Conservative-Liberal Democrat coalition in

\footnotetext{
${ }^{46}$ Joseph Stiglitz, "Austerity has been an utter disaster for the Eurozone", The Guardian, 1 October 2014.

${ }^{47}$ Paul Krugman, “A game of chicken”, The New York Times, 6 February 2015.
} 
the UK announced the largest cuts in State spending since World War II. In Germany, and notwithstanding the fact that unemployment was at 7 percent at the time, plans were made to cut the deficit in $€ 80$ billion by 2014. No one in the region got it lightly. ${ }^{48}$

These austerity measures were being imposed on populations that were already suffering the effects of the economic contraction due to the United States financial crisis, globalization and automation. Edward Luce refers to the most affected sectors as follows: "In Britain we call them the 'left-behinds'. In France, they are the 'couches moyennes'. In America they are the 'squeezed middle'. A better term is the 'precariat' - those whose life is dominated by economic insecurity". 49

Not surprisingly, the accumulated grievances of this "precariat", and of the unheard citizens, have created a sort of counter-society, which looks at fresh and more inclusive political options. Thanks to it, the political fringes are becoming mainstream and newly created parties are moving into center stage. Meanwhile, traditional parties are quickly eroding (as it is the case in Europe), or moving towards the extremes of the political spectrum.

While conservative parties are evolving into the extreme right, many center-left parties seem to be imploding. The Socialists in France went from holding government to receiving just 7 percent of the vote in the 2017 presidential election. In the Netherlands, the Labor Party share of the vote fell from 24.8 percent in the 2012 general election to just 5.7 percent in 2017, dropping from 150 members of Parliament to just nine. Germany's historic Social Democratic Party fell behind the newly formed Alternative for Germany. The Czech Social Democrats, who had received around onethird of the popular vote in 2006, collapsed in the 2017 elections, winning only 7.3 percent of the vote. And so the list goes on. ${ }^{50}$

Both in Europe and the United States, economic disruption sparked social unrest, which in turn produced major political disruption. Even the

\footnotetext{
48 "EU austerity drive country by country", BBC News, 21 May 2012.

${ }^{49}$ Edward Luce, op. cit., p. 136/4115.

${ }^{50}$ William A Galston, "The Rise of European populism and the collapse of the center-left", Brookings, 8 March 2018, https://www.brookings.edu/blog/order-from-chaos/2018/03/08/ the-rise-of-european-populism-and-the-collapse-of-the-center-left/. Accessed 10 April 2018.
} 
World Economic Forum recognizes this: "The growing gap between the rich and the poor, the old and the young, has been largely ignored by policymakers and investors until the recent rise of anti-establishment votes, including those for Brexit in the UK and for President Trump in the US... Inequality is much more than a side-effect of free market capitalism. It is a symptom of policy negligence...Capitalism has been incredibly successful at boosting wealth, but it has failed at redistributing it". ${ }^{1}$

Populism, indeed, is becoming the new political home for an emerging majority in both Europe and in the United States. For many populists, though, a world socially and economically turned upside down only accounts for half of their resentment story. Immigration tells the other half. As David Brooks says: "In times of anxiety and distrust, it's a lot easier to sell us/them distinctions than tolerance for cultural diversity". ${ }^{52}$ If so, the anxiety of economic exclusion becomes the ideal breeding ground for intolerance against the foreigner. Particularly so, when ethnic and cultural diversities are involved.

\section{Immigration: The Other Half of the Resentment Story}

Current immigrants to the United States mostly come from China, India, the Philippines, Vietnam and Latin America. Almost a fifth of total legal immigrants, and the majority of the illegal ones, come from one single country: Mexico. The impact of the "Latino Americanization" of the United States is transforming the US into a bilingual society. By 2015, there were almost as many Spanish speakers in that country as in Spain itself: 41 million. According to the US Census, there will be 138 million Spanish-speaking US citizens in 2050. ${ }^{53}$

Much to the point, Samuel P. Huntington wrote about the strong possibility of the United States becoming a bifurcated society “...in terms of language (English and Spanish) and culture (the Anglo-Saxon and the

\footnotetext{
${ }^{51}$ Alberto Gallo, "How the American dream turned into greed and inequality", World Economic Forum, https://www.weforum.org/agenda/2017/11/the-pursuit-of-happinesshow-the-american-dream-turned-into-greed-and-inequality/. Accessed 12 December 2017. 52 "Vladimir Putin, the most influential man in the world", The New York Times, 2 April 2018.
}

${ }^{53}$ Stephen D King, op. cit., p. 156. 
Hispanic) ... Substantial portions of the United States, particularly Florida and the Southwest, would end up being essentially Hispanics both in terms of culture and language, with both cultures and languages coexisting. The United States, hence, would loose its cultural and linguistic unity, transforming itself into a bilingual and bicultural society such as Canada, Switzerland or Belgium". ${ }^{4}$

What Huntington failed to mention, and many of the current rejecters of Latin American presence in the US seem to forget, is that what drives Hispanic population growth is the children or grandchildren of the immigrants. Conversely, the number of Latino immigrants into the country continues to decline. Two out of every three Hispanics in the United States today were born there. Indeed, every year one out of four babies born in the United States is born to a Latino mother. Three-quarters of Hispanics or Latinos are thus US citizens.

Moreover, many members of the Latino community trace their ancestry to places that were incorporated into the United States by conquest or war. In other words, their forefathers lived there before those territories became part of the United States. The descendants of families, who inhabited what is now Southwestern United States, could very well say "We didn't cross the border. The border crossed us". This means that they belong to families that for generations have enjoyed US citizenship.

The extreme measures against Southern immigrants taken by the Trump Administration bear no relation to the actual magnitude of the said immigration. On the contrary, they seem to be more in tune with the anxieties related to the changing racial landscape of the United States. According to Brookings Institute: "What is new is that Trump is clearly capitalizing on what The New York Times columnists Charles Blow has termed 'white extinction anxiety'. 'For the first time since the Census Bureau has released these annual statistics' wrote Brooking demographer William Frey, 'they show an absolute decline in the nation's white nonHispanic population - accelerating a phenomenon that was not projected to occur until the next decade'...The racial makeup of the United States

\footnotetext{
${ }^{54}$ Samuel P Hungtinton, Quiénes Somos? Los Desafíos de la Identidad Nacional Estadounidense (Barcelona: Paidós, 2004), p. 45.
} 
may change, but when white power lies in the balance, the unspeakable becomes acceptable". ${ }^{5}$

So, it seems that Trump achieves his ongoing popularity, within his Republican base, by way of reassuring them against the anxieties of the white population losing its majority status in the United States. Hispanic immigrants may turn out to be, under this argument, simple scapegoats within a larger picture. As Brookings stated: "A second noteworthy finding from the new census estimates is that, for the first time, minorities outnumber whites nationally for each age under 10 ". ${ }^{56}$

Within the European Union, the dramatic eastward expansion and the lack of border controls established by the Schengen Agreement (of which only the UK and Ireland are not part), were sources of malaise for many. In the UK, where the former but not the latter was a huge problem, the prevailing uneasiness was explained by Rowena Mason as follows: "Public unease has been fuelled by a failure to prevent immigration from piling pressure on jobs markets and public services, and a refusal by politicians to acknowledge the sheer numbers of Europeans making new homes in the UK after the EU's expansion to the east in 2004 and 2007". ${ }^{7}$

Being overflowed by Romanian or Polish citizens was indeed resented by many Western Europeans. However, this pales in comparison to the indiscriminate arrival of people from the Middle East or Africa. In 2015, more than twice as many people as in the previous year sought asylum in the European Union. Syria, Iraq and Afghanistan, the three least peaceful countries in the world, were the three biggest sources of asylum seekers in Europe that year. ${ }^{58}$

In Stephen D. King words: "Whatever the humanitarian need of the refugees themselves, the numbers arriving in the EU created a serious challenge to Schengen and, by implication, to the EU's very existence". ${ }^{59}$

\footnotetext{
${ }^{55}$ Andrew M Perry, “Trump reveals 'zero tolerance' for democracy”, 25 June 2018, https:// www.brookings.edu/blog/the-avenue/2018/06/25/trump-reveals-zero-tolerance-fordemocracy/?. Accessed 27 June 2018.

${ }^{56}$ Ibid.

${ }^{57}$ Rowena Mason, "How did UK end up voting to leave the European Union?", The Guardian, 24 June 2016.

${ }^{58}$ Rowena Mason, Ibid.

${ }^{59}$ Stephen D King, op. cit, pp. 165-166.
} 
Indeed, Schengen represented a very different proposition when Eastern Europeans could freely move to Western Europe, than when admitted Middle Eastern immigrants can freely circulate within the whole European Union.

With her generous policy towards Syrians refugees, Angela Merkel compounded the situation. After taking in more than 1 million refugees and asylum seekers in the previous two years, in August 2015, she declared that her country was prepared to receive hundreds of thousands more. This not only transformed Europe into a magnet for displaced Syrians and Middle Easters, but also was accompanied by Germany's pressure to have an EU mandatory quota system for refugees.

There is no need to point out that her immigration initiatives, combined with her policy towards Greece (and the PIIGS in general), and her staunch support for austerity measures capable of maintaining national deficits under control, helped to ignite the populist insurgence in Europe. And so, by a rather curious historical twist, Ms. Merkel, the most important globalizer of the day, became the main promoter of European populism.

\section{The Populist Flood}

Therefore, immigration adds to the list of grievances for many dissatisfied citizens. Populism, as said, has become the great beneficiary of this huge dissatisfaction against the status quo, unleashing a political wave that currently floods both the United States and Europe. The common denominator of all these populist parties and movements is their anti-system character. They present themselves as expressions of the people and of its interests against the traditional elites. Within their credo, a dichotomy exists between the forgotten social majority and the privileged few, meaning, the establishment, the oligarchy, the plutocracy or the "cast". Their grievance is directed against deaf, selfish, arrogant and corrupt political elites, which are complicit with the excesses and greediness of big corporations and a wealthy class.

Although common to them all, their notion of "people" is rather lax. All sorts of groups may represent "the people": depressed social sectors, displaced workers, indebted students, threatened small retailers, and such 
like, hence the predilection of so many of these parties for direct democracy, in which the people are able to express their will through plebiscitary mechanisms, and without the constraints of an elite's controlled representative democracy.

And then, there is the common element of the perceived foreign threat. For all of them, globalization plays that role, having become the main disruptor of their societies and the main enemy of their middle classes. This enmity encompasses, by extension, a wide array of international or multinational institutions or initiatives that goes from the World Trade Organization to Davos; from the international financial markets to free trade agreements and the International Monetary Fund.

For European populists, this includes the European Union as well, an institution that systematically underestimates the will of the people, and is being seen as a neoliberal-oriented organization in tune with the business elites. Moreover, the austerity policies established under its guard were profoundly resented. The ECB also falls under this category.

The foreign threat also has for many, if not for all, another face: immigration. For this group of populists, immigrants are seen as a true plague that is transforming and deforming the traditions and the national character of their societies, while presenting an unfair competition for their own workers. The animosity against it encompasses, by extension, traditional parties, governments or supranational organizations, seen as supportive of this foreign avalanche.

In John B. Judis words: "Populist parties and candidates are on the move in the United States and Europe. Donald Trump has won the Republican nomination; Bernie Sanders came in a very strong second to Hillary Clinton for the Democratic nomination. And these candidacies came on the heels of the Tea Party and Occupy Wall Street movements. In Europe populist parties in France, Sweden, Norway, Finland, Denmark, Austria, Greece, Italy, Spain and Switzerland are contending for power or are already part of the government" ${ }^{60}$ Soon after John B. Judis' appraisal of the situation, Trump obtained the presidency of the most powerful nation on Earth and populism became the main opposition force in Germany.

${ }^{60}$ John B Judis, op. cit., p. 12. 


\section{On the Move}

During the run up to the American election, populism from both parties played a forceful role. Sander's populist bid almost got him the nomination of the Democratic Party, while Trump's got him the White House. This show of strength was also replicated on the other side of the Atlantic, where populism is shaking the status quo both from the hard right and from the extreme left. While in the US, the two traditional parties have been assaulted from the inside by populism, in Europe fringe or newly created populist parties have become mainstream, attaining power in many cases.

In Italy's March 2018 parliamentary election, the Five Star Movement won 32.7 percent of the vote, while the League (formerly the Northern League), obtained 17 percent. Populism, in its different versions, clearly dominated the country. Extreme right- and left-wing Italian populists reached an agreement to form a consensus government among them. This was preceded by the election of a new Speaker of the Chamber of Deputies agreeable to both.

The President of the Italian Republic, though, refused to appoint the Prime Minister that they had selected and went on for a caretaker government who would be responsible of summoning fresh elections. It was the establishment's reaction against the populist triumph, wanting to put in motion the well-known practice of keeping the citizens voting until they did it "right". As events unfolded, however, the caretaker government could not be formed and the President was forced to appoint a populist government under the Prime Minister that he had initially rejected.

The party Alternative for Germany, which started in 2013 as a protest movement, won up to 25 percent of the vote in the German state elections of March 2016. Moreover, in Germany's parliamentary elections of September 2017, the party, widely known by its German initials AfD, obtained 92 MPs and around 13 percent of the vote. Conversely, the ruling Christian Democrats got the worst result since 1949, while the Social Democrats, its main opponents, scored their lowest electoral results in a century.

The political cataclysm caused by this sudden emergence of populism in Germany brought with it several consequences. After six months of negotiations, Angela Merkel barely managed to form a government with 
a frail coalition. Populist AfG on its side, became the main opposition party. According to The New York Times: "Ms. Merkel will limp on as chancellor. For how long is unclear. The nationalism and anti-migrants sentiment that has challenged multilateralism elsewhere in Europe is taking root — fast — in mainstream German politics". ${ }^{61}$ The country, long regarded as Europe's model of stability and political maturity, has definitely changed.

In France, the National Front (FN) came first in the regional elections of December 2015, obtaining 27.73 percent of the vote, although all other parties joined forces to prevent its victory. The previous year, it also had arrived first in the European parliamentary election with 24.8 percent of the ballots. Its candidate was one of the two frontrunners in the first round of the 2017 presidential election, arriving second in the final round with 34 percent of the vote. Although its opponent was elected President, the norm being that whoever opposes FN's candidate in the second round concentrates the rest of the electorate, the FN won both in the North and the South of the country.

In Denmark, the People's Party (DF) came in second in the June 2015 parliamentary elections obtaining 21.1 percent of the vote. In Austria's presidential election, the Freedom Party (FPO) candidate came first in the first round of the April 2016 presidential election, being defeated by few points in the second round. However, FPO won the parliamentary election of October 2017. In Switzerland, the Swiss People's Party (SVP) came in first in the October 2015 parliamentary election, with almost 30 percent of the vote.

In Norway, the Progress Party (FrP) has been part of the governmental ruling coalition since 2013. In Sweden, the Sweden Democrats party (SD), won about 13 percent of the vote in the parliamentary elections of September 2014. Because none of the traditional parties would form a coalition with them, the country has been governed by a shaky minority coalition. In the Netherlands, the Freedom Party (PVV) arrived at the second position in the March 2017 parliamentary elections.

Britain's United Kingdom Independence Party (UKIP) was at the forefront of the successful Brexit campaign of June 2016. In Rowena Mason

\footnotetext{
${ }^{61}$ Katrin Benhold and Melissa Eddy, "Merkel to survive, agrees to border camps for migrants", 2 July 2018.
} 
words: "Cameron might never have called the referendum had it not been for the rise of Nigel Farage and UKIP. By January 2013, when the prime minister called the EU vote, UKIP had started to gain traction in local elections and was polling double digits for the first time...Even after promising the referendum, Farage managed to gain millions of votes in the 2015 election, many of them in Labour areas as well as Conservatives". ${ }^{62}$

In Spain, in the December 2015 and June 2016 parliamentary elections, the Podemos Party created in 2014, arrived third and at a short distance from the Socialist Party (PSOE) and of the winning Popular Party (PP). It won 22 percent and 21 percent of the vote, respectively. In Greece also, the recently founded Syriza Party came first in the two parliamentary elections held in 2015 with around 35 percent of the vote, thus taking charge of the government.

According to Steven Erlanger: "The four countries of the European Union's East that made older member anxious - Poland, Hungary, the Czech Republic and Slovakia - are all led by populists of one stripe or the other...And the fact that populists now run governments in Eastern and Central Europe threatens to further legitimize movements that once sat on the political fringe" ${ }^{63}$ It must be added that in the elections held in June 2018, the populist also won the majority of the vote and formed a government in another Eastern member country of the EU: Slovenia.

Law and Justice in Poland, Fidesz in Hungary, Action of Dissatisfied Citizens (ANO) and Freedom and Direct Democracy in the Czech Republic, the Slovak National Party, the People's Party of Slovakia and We Are Family in Slovakia and the Slovenian Democratic Party in Slovenia, are all expressions of this tide.

\section{What Does Populism Stands for?}

In order to understand better what populism stands for, a double distinction is in line. On the one side, there is left-wing populism and right-wing populism; on the other side, there is European populism and US populism.

\footnotetext{
${ }^{62}$ Rowena Mason, op. cit.

${ }^{63}$ Steven Erlanger, "In Eastern Europe, populism lives, widening a split in the EU", The New York Times, 28 November 2017.
} 
John B. Judis believes that the main difference between left-wing and right-wing populism is the following one: "Leftwing populists champion the people against an elite or an establishment. Theirs is a vertical politics of the bottom and middle arrayed against the top. Rightwing populists champion the people against the elite that they accuse of coddling a third group, which can consist, for instance, of immigrants, Islamists or African American militants. Leftwing populism is dyadic. Rightwing populism is triadic. It looks upward, but also down upon an out group". ${ }^{64}$

This looking down upon a certain group of people, essentially immigrants, makes the fundamental difference between both kinds of populism. While right-wing populism makes a strong distinction between the "we versus them", Sanders' populism overtly advocates for a "humane immigration reform", by "creating a path for the 11 million undocumented people in our country to become lawful permanent residents, and eventually citizens". ${ }^{65}$

However, there is more to that distinction than immigration. Leftwing populists are clearly favorable to public spending and economic redistribution, which tends not to be the case with their right-wing counterparts. In Europe, theirs would essentially be a soft Euroscepticism in contrast to a hard Euroscepticism or Europhobia, more common to rightwing populism. Nationalistic and xenophobic expressions and messages would be common in right-wing populism, whereas its leftist version avoids nationalistic or xenophobic undertones.

Also, in the case of Europe, left-wing populism is identified with late or least developed countries or regions, which essentially identifies with Southern Europe. This would be the case of Greece and Spain. Italy is more of a hybrid, as it reproduces this dichotomy within its own territory. The northern part, which is more developed and richer, shows strong right-wing populism, whereas the southern part follows essentially a leftwing one.

The per capita income in prosperous northern Italy, at around $€ 32,000$, is on par with Germany, France and the UK. Per capita incomes in southern Italy — the so-called Mezzogiorno — are only around $€ 7,000$, on par

\footnotetext{
${ }^{64}$ John B Judis, op. cit., p. 14.

${ }^{65}$ John B Judis, Ibid, p. 400.
} 
with Slovenia, Greece and Portugal. The gap that exists within Italy, thus, is as big as the gaps across much of Europe. ${ }^{66}$

It is important to add, nonetheless, that the Five Star Movement which dominates the Italian "Mezzogiorno", considers itself to be a transversal party rather than a left-wing one, meaning by this to be a political aggrupation where disillusioned citizens, from left or the right, can find a space. The same applies to Spain's Podemos. Nonetheless, both of those parties are considered to be left-wing because their constituencies are mostly aligned in that direction, and their policies clearly differ from those of the right-wing counterparts.

As numbers go, compared to left-wing populism, the right-wing one is a much bigger group. From Trumpism, which is today the new face of the Republican Party, to the rest of the European right-wing populists, theirs is indeed a larger gathering. Right-wing, though, may not be the correct category to include these parties in, as they are clearly hard right.

Several of the parties of this European hard right populism are grouped in the so-called Movement for a Europe of Nations and Freedom (MENL). They work together as a parliamentary group within the European Parliament, where they were recognized as a political block in 2015. However, not all of them are equally interested in actively participating at this level, given their prevailing contempt towards the European Union.

\section{European Populism vs. American Populism}

There also exists an important distinction between European populism and its US counterpart. The plurality of political parties within the European political scene, in tune with the parliamentary political system of the majority of its countries, allows for fringe parties to survive. It also allows for the creation of new parties.

As a result, many populist parties existed for quite some time on the outskirts of their political systems before thriving, in the same manner in which others moved into the mainstream after having been recently created. In Stephen D. King's words: “...parties have either emerged from

${ }^{66}$ Stephen D King, op. cit., p. 219. 
nowhere or chased electability from the political fringes" ${ }^{67}$ This undoubtedly eased their steadfast moving into center stage when the right conditions emerged.

In the United States, the rigid two-party system and the existence of the Electoral College, takes away any chance of success by a populist party. Even Ross Perot, who ran two of the strongest presidential showings by a third party or an independent candidate in US history, had no chance of success. In the 1992 election, he received 18.9 percent of the popular vote, about 19,741,065 votes, but did not get any Electoral College vote. In 1996, after having founded the Reform Party, he received 8 percent of the popular vote, but again not a single Electoral College vote. He showed that populism had an important support in the country, although he also made evident the impossibility of winning the presidency from outside the two-party system.

Hence, the only chance that populism has in the US is by conquering one of the two traditional political parties from the inside. The first recent populist movement that tried to do that was the Tea Party. Although its grasp on the Republican Party proved to be very important, with 62 vociferous members in the House of Representatives, it remained clearly insufficient to obtain the control of the party. The 2016 Presidential Election was to become a landmark, as both Bernie Sanders and Donald Trump emerged as formidable populist candidates within the two-party system.

In June 2016, David Brooks wrote a very important piece in his The New York Times column. According to him, Donald Trump completely changed the nature of the political debate in the United States. Until then, and for the last 80 years, the debate had been centered in the dichotomy more State vs. less State. While Democrats represented the former, Republicans called for the latter. Trump was able to move the debate into a completely different direction: a dichotomy between openness vs. closeness. That meant being open to the world and to a globalized international society or, alternatively, putting strict limits to free trade, establishing rigid barriers to immigration, diminishing international commitments and giving free rein to the mistrust against all

${ }^{67}$ Stephen D King, op. cit., p. 101. 
things foreign. This new debate, in Brooks' view, was to remain in place for decades to come.

Bernie Sanders also represented a variation of the traditional debate, but in a much more restrained form. He rejected globalization to be certain, and proposed a much more nationalistic approach to economics. However, he did not have a quarrel with immigration, nor did he mistrust the foreign world per se. Moreover, he was very much into the traditional argument of more State, although with a populist tone: "We have to forcefully take on the arrogance and greed of the ruling class". ${ }^{68}$

With a difference of degrees, thus, 2016 was a different campaign, as strong candidates in both parties had a message that until then had essentially remained on the fringe of American politics. The new message, though, was directly related to poll numbers. In 2002, Pew Research found that 78 percent of Americans supported global trade. In 2008, that percentage had fallen to 53 percent. In 2014, when Pew asked if international trade improved the livelihood of Americans, only 17 percent thought that it led to higher wages, while only 20 percent believed that it created new jobs. ${ }^{69}$

Bernie Sanders did not only display an impressive show of force, but even while losing the candidacy, he was able to bend the globalizer per excellence, Hillary Clinton, to his anti-globalizing proposals. Moreover, such a stance has arrived to stay. The so-called Progressive wing of the Democratic Party is currently providing it with a boost of activism and energy and, if Donald Trump is to be defeated in 2020, it would be likely by way of a populist attack to his left flank.

Indeed, it seems unlikely that traditional politics and traditional messages will get Trump out of the White House. In Edward Luce terms: "Many comfort themselves that Trump's victory was an accident delivered by the dying gasp of America's white majority — and abetted by Putin. History will resume normal business after a brief interruption. How I wish they were right. I fear they are not". ${ }^{70}$

\footnotetext{
${ }^{68}$ Bernie Sanders, op. cit., p. 87.

${ }^{69}$ T. X. Hames, "Will technological convergence reverse globalization", Strategic Forum, National Defense University, July 2016, http://ndupress.ndu.edu/Portals/68/Documents/ stratforum/SF-297.pdf. Accessed 12 May 2018.

${ }^{70}$ Edward Luce, op. cit., p. 138/4115.
} 


\section{The Trump Factor}

The reasons for this are clear. According to a Pew Research Center poll, 81 percent of Trump supporters thought life for people like them had gotten worse over the previous 50 years, while only 11 percent thought it had got better. Moreover, Trump supporters were deeply pessimistic about the future, with 68 percent believing that the lives of the next generation would be even worse. ${ }^{71}$ Not surprisingly, The Economist said: "Populism wave has yet to crest". ${ }^{72}$

Populism, indeed, will take time to crest, as the reasons that gave it rise are not bound to disappear any time soon. With robots and computers taking down jobs at amazing speed (replacing in the process the competition of low-cost workers such as those from Vietnam or Indonesia), and with immigration following its course, as wars and hunger abroad are a fact of life, populism seems to have become the new normal.

Trump was not only capable of winning the White House but, subsequently, of conquering the Republican Party most thoroughly. Asking himself about the reasons that made Trump so successful, Martin Woolf explains: "Yet, as Robert Kagan, a neoconservative intellectual argues in a powerful column in the Washington Post, Mr. Trump 'is also the GOP's Frankenstein monster'. He is, says Mr. Kagan, the monstrous result of the party's 'wild obstructionism', its demonization of political institutions, its filtration with bigotry and its 'racially tinged derangement syndrome' over President Barak Obama...Why has this happened? The answer is that this is how a wealthy donor class, dedicated to the aims of slashing taxes and shrinking the state, obtained the foot soldiers and voters it required, This, then, is 'pluto-populism': the marriage of plutocracy with right-wing populism. Mr. Trump embodies this union. But he has done so by partially dumping the free-market, low tax, shrunken government aims of the party establishment, to which his financially dependent rivals remain wedded". ${ }^{73}$

In other words, Trump not only gave voice to the anger of America's squeezed middle, but he profited from the table that the Koch brothers had

\footnotetext{
${ }^{71}$ Stephen D King, op. cit., p. 241.

72 "Left behind", The Economist, 21-27 October 2017.

73 "Donald Trump embodies how great republics meet their end", Financial Times, 1 March 2016.
} 
already served. They had been playing with political fire in order to get the "foot soldiers and voters" to support their patrimonial agenda. Trump just needed to turn that fire against the plutocrats and the establishment. And he did so quite adroitly. Being a billionaire himself, he did not need the Koch's money, and hence was free to define his own rules of the game. Being an expert in reality shows, he was able to take advantage of the anger that they had been flirting with, projecting it to maximum intensity decibels. His was, no doubt about it, a hostile takeover of Koch Inc., meaning the Republican Party.

And, indeed, it has been a successful takeover. As expressed by The Economist: "All presidents, Republican and Democrats, seek to remake their party in their own image. Donald Trump has been more successful than most. From the start, the voters he mesmerized in the campaign embraced him more fervently than congressional Republicans were ready to admit. After 15 months in power, as our briefing explains, he has taken ownership of the party". ${ }^{74}$ The New York Times agrees: "The President transformation of the G.O.P. — its policies, its tone, even the fate of its candidates - has never been so evident. A party that once championed free trade has become protectionist under Mr. Trump. Sermons about inclusivity have been replaced with demagogic attacks on immigrants...". ${ }^{75}$

Thomas L. Friedman goes further: "The U.S. Republican Party has blown up in all but name, going overnight from an internationalist, free trade, deficit-hawk party to a protectionist, anti-immigrant, deficit-dove party - all to accommodate the instincts of Donald Trump and his base. As the former House Speaker John Boehner noted: 'There is no Republican Party. There's a Trump party"'. ${ }^{76}$ President Trump, as The New York Times reported on June 24, 2018, enjoys the support of 90 percent of his party.

Again, The Economist says: "Because the party was becoming Trumpian long before Mr. Trump took over, it will no more go back to the

\footnotetext{
74 "What has become of the Republican Party", The Economist, 21st-27th April 2018.

${ }^{75}$ Jonathan Martin and Michael Tackett, "Republicans absorb new lesson: Cross president Trump at their peril", 13 June 2018.

${ }^{76}$ Thomas L Friedman, "Why are so many political parties blowing up? (Part 1)", The New York Times, 26 June 2018.
} 
1980 s in his absence than to 1880 s... But the attitudes he has ridden to office will still outlive him". ${ }^{77}$ Not surprisingly, the same article quotes Andrea Volkens, of the Berlin Social Science Center, saying that the Republican Party sits much closer today to France's FN than to the Conservatives in Britain. Hence, the Republican Party, and not just the current occupant of the White House, are within the populist camp. As such, and for the foreseeable future in the United States, populism will be a force to reckon with.

But the anti-globalization camp does not stop here. From both extremes of the political spectrum, rejection to all that this movement represents is very much alive. As much of the hard right within the developed economies has fusioned itself with populism, there does not seem to be much else to look for in that direction. On the contrary, several expressions of left-wing anti-globalization still subsist outside the frame of populism. This is clearly the case of Jeremy Corbyn in the United Kingdom and, to a lesser extent, that of Jean-Luc Mélenchon in France.

\section{The Comeback of the Extreme Left}

Jeremy Corbyn's positions are very much in tune with UK policies of the 1970s: nationalization, council house building and government-planned industrial strategy. Moreover, they seem to come from a very specific source within the Labour Party itself: Tony Benn. He was the architect of the 1983 Labour manifesto, which in those years shaped much of the party's ideas. Far left-wing politics of the 1970s and the 1980s are thus back in fashion, courtesy of the social disruptions brought up by globalization. As Thomas L. Friedman correctly points out: "Britain's Labour Party has gone from the center-left to quasi-Marxist". ${ }^{78}$

As a result, a marginal figure within the Labour Party of the past three decades like Jeremy Corbyn, has moved into the center stage of British politics. Under his leadership, the party won 40 percent of the vote in the 2007 general election, its highest since 2001, and came close to dislodging the Conservatives from power. Meanwhile, his presence at the top of the

\footnotetext{
77 "How the elephant got its Trump", The Economist, op. cit.

${ }^{78}$ Thomas L Friedman, op. cit.
} 
party has been instrumental in doubling its ranks to 552,000 members. But it was not the nostalgic oldies who brought him there, but the millennials, who as in the case of Bernie Sanders, are his more enthusiastic supporters. A grassroots activist group, known as Momentum, played a key role in electing Corbyn as leader by energizing a young and online base. His success was the product of an internal insurgency, which has allowed him to be in the anteroom of 10 Downing Street, in spite of having been rejected by much of the establishment of his party. That says much about the strength of the anti-globalization movement in the UK. ${ }^{79}$

Corbyn's stance in this matter is emblematic. Even Gordon Brown, curiously enough, recognizes the significance of his anti-globalization position. Referring to Brown's opinion, Rob Merrik says: "Mr Corbyn was successfully tapping into rising public anger over the unfair effects of globalization, after centrists appeared to show they had 'no answers', Mr. Brown said. 'People feel rightly or wrongly that the problems that they have - stagnant wages, inequality, polarization between rich and poor, public service not being properly financed — they ascribed that to the failures of governments, centrist governments that have not been able to manage globalization', he said. On Mr Corbyn shock rise, Mr Brown said: 'He has come through because he expresses people's anger at what's happened - the discontent. When he attacks universal credit, he is speaking for many people, when he says the health service is underfunded, he is speaking for many people'...In the interview, Mr Brown denied he was moving to the left, but argued Mr Corbyn's success was because New Labour 'did not finish the job of curbing inequality and bad banking practices. He has 'articulated a view of a fairer society' by pinching the 'for the many not the few', he noted", ${ }^{80}$

Another important European anti-globalization far-left figure is France's Jean-Luc Mélenchon. After splitting from the Socialist Party, following its defeat in the 2007 election against Sarkozy, he formed the Left Party, which lingered on the sidelines of French politics for a few

\footnotetext{
${ }^{79}$ Naomi O’Leary, “Europe left looks to Jeremy Corbyn”, Politico, 29 July 2018, https:// www.politico.eu/article/jeremy-corbyn-labour-left-left-look-to-corbyn/. Accessed 4 August 2018.

${ }^{80}$ Rob Merrik, "Gordon Brown backs Jeremy Corbyn as Labour leader: 'People want to see change"”, The Independent, 10 November 2017.
} 
years. However, during the 2012 presidential election, Mélenchon received 11.1 percent of the vote, being placed in the fourth position on the first round. Having founded a new party called La France Insoumise in 2016, he was again a candidate for the presidential election of 2017.

He received 19.58 percent of the votes in the first round of that election, being again placed number four but at a short distance from the other competitors. Indeed, he was just 4.5 points away from Emmanuel Macron and less than two points from Marine Le Pen, who went on to the second round. Moreover, he tripled the score of the mainstream Socialist Party, whose collapse elevated Mélenchon as the de facto leader of the French left.

For many analysts, though, Mélenchon's strong standing in the last presidential election was due to the fact that he moved from traditional left-wing positions into populist ones, immigration excluded. He can, indeed, be considered borderline in relation to populism.

What admits no doubts, though, is Mélenchon's anti-globalization stance, or better put, his alter-globalization one. The difference being that the latter supports global cooperation and interaction, but opposes what it describes as the negative aspects of economic globalization. In other words, it does not oppose economic globalization per se, but the fact that major corporations enrich themselves at the expense of common people and the environment. Alter-globalization is also highly critical of the role played by international organizations such as the World Trade Organization or the International Monetary Fund.

In his last presidential campaign, Mélenchon threatened with taking France out of WTO, referred to bankers as "parasites" who "produce nothing", while saying that free trade "destroys everything" and leads to the "total perversity" of social dumping. ${ }^{81}$ Moreover, he expressed that "the leveling of the world economy will lead ineluctably to a global race-tothe-bottom....as workers in developed countries are forced to compete with foreign workers who can produce the same goods at a fraction of the price". He also called for "the radical renegotiation or abandonment of European treaties". 82

\footnotetext{
${ }^{81}$ Michel Stothard, "Jean-Luc Mélenchon barges way into tight French presidential race", Financial Time, 17 April 2017.

${ }^{82}$ Harrison Stetler, "The Rise of Jean-Luc Mélenchon and France's 'Post-Democracy", The New Republic, 18 April 2018.
} 
If the favorite child of Western globalization, Emmanuel Macron, fails to deliver the many expectations that he created in the 2017 campaign, there will not be a safe net for establishmentarian parties. Backlash will be inevitable. As both the Republicans and the Socialist parties suffered historical defeats and fragmented in the 2017 elections, they appear to be far too weak for leadership in the 2021 presidential elections. Hence, Marine Le Pen and Jean-Luc Mélenchon could end up being the frontrunners that year, which entails undoubtedly a dim prospect for globalization.

\section{Putin: The Godfather of Populism}

And then, in a totally different category, we find Vladimir Putin. His ideas have much in common with those of hard-right populists. Of course, not that Russia matters all that much in the global trade equation, energy excluded, but it becomes relevant due to its closeness to Western populists. This closeness expresses itself in three ways: first, through the Kremlin cyber-campaigns on their behalf; second, by their looking at Putin's ideas as role models; third, by seeing Russia as a natural ally.

As Sholmo Ben-Ami puts it: "According to Gerard Araud, France's ambassador to the United States, Russian electoral interference and manipulation, if left unchecked, could pose an 'existential threat' to Western democracies. In other words, an autocrat ruling over an impoverished country with an oil-addicted economy smaller than that of Brazil is supposed to be capable of bringing down the world's major democracies... Russia's cyber-campaign against the centrist Emmanuel Macron - meant to aid the far-right candidate Marine Le Pen — included everything from the publication of baseless claims that Macron is gay to the diffusion of fake documents claiming that he has an offshore bank account". ${ }^{83}$ The list of Russian political interference on behalf of Western populist candidates is long. That, of course, includes Donald Trump.

On the other hand, Putin has articulated a group of conservative ideas - attacking the "fetishization" of tolerance and diversity, the

\footnotetext{
${ }^{83}$ Sholmo Ben-Ami, "The threat to Western democracy starts at home", The Strategist, Canberra: Australian Strategic Policy Institute, 31 March 2018, https://www.aspistrategist. org.au/threat-western-democracy-starts-home. Accessed 14 May 2018.
} 
excesses of moral relativism, the denying of traditional identities, samesex partnerships and marriages, etc. This has transformed him into the hero of far-right populism. In Franklin Foer words: "But right-wing leaders around the world — from Rodrigo Duterte in the Philippines to Nigel Farage in Britain to Donald Trump in the U.S. - now speak of Putin in heroic terms". ${ }^{84}$

But were those ideas sincere or opportunistic? Again, according to Foer: "After the global crisis of 2008, populist uprisings had sprouted across Europe. Putin and his strategists sensed the beginnings of a larger uprising that could upend the Continent and make life uncomfortable for his geostrategic competitors... With the traditionalist masses ripe for revolt, the Russian president had an opportunity. He could become... 'The New World Leader of Conservatism"'. ${ }^{85}$ Opportunism, it seems, was the nature of the game.

For hard right populists, though, the perceived commonalities with Putin make of him a natural ally. As Ronal Brownstein expresses: "But conservative-populist nationalists in both the United States and Europe view Putin as a potential ally because they are focused on a sharply contrasting set of international priorities: resisting Islamic radicalization, unwinding global economic integration, and fighting the secularization of Western societies...European populist parties share a common set of priorities focused on restricting immigration, unwinding global economic and political integration (by renouncing the European Union, and, for some of these parties, NATO as well), taking tougher steps to fight Islamic radicalism, and, in most cases, opposing cultural liberalism and secularization at home. On all those fronts, they view Putin not as a threat, but as an ally". ${ }^{86}$

While referring to the Trump-Putin summit, held in Helsinki in July of 2018, Robert Kagan confirms the above: "What observers could not see, was that this was not a meeting between adversaries. It was a meeting between allies, with convergent interests and common goals. These, incidentally, have nothing to do with the 2016 election. They have to do with

\footnotetext{
${ }^{84}$ Franklin Foer, "Its Putin World", The Atlantic, March 2017.

${ }^{85}$ Ibid.

${ }^{86}$ Ronal Brownstein, "Putin and the Populists", The Atlantic, 6 January 2017.
} 
a common view of the liberal world order that the United States helped create seven decades ago. Both leaders seek its destruction". ${ }^{87}$

It would be naïve not to assume that what really matters to Putin's Russia is the objective of undermining, from the inside, Western power and stability. This, by way of deconstructing the Western's democratic post-war establishment, through the weakening of the American-led network of alliances and rules (particularly NATO) and by the collapse of the European Union. Populism becomes, under this perspective, a formidable tool on behalf of Russia's geopolitical aims.

Putin's anti-globalization stance, though, is of secondary relevance, given Russia's modest role within it. What really matters, from a globalizing perspective, is his manipulation of the anti-establishment sentiment prevailing in Western societies so as to disrupt the status quo most thoroughly. The following assertion by David Brooks seems, thus, to make sense: "Who is the most influential human being on the planet? My vote goes to Vladimir Putin". ${ }^{88}$

In conclusion, Western post-cold war consensus on globalization is falling apart as a result of the divisive nationalism that a rising populism is bringing with it. As the French Minister of Finance Bruno Le Maire warned at the G20 summit at the end of July 2018: "World trade cannot base itself on the law of the jungle... The law of the jungle, the law of the fittest. This cannot be the future of the global trade relations. The law of the jungle will only turn out losers, it will weaken growth, threaten the most fragile countries and have disastrous political consequences". ${ }^{89}$ Unfortunately, we have indeed entered into the law of the jungle with major economies imposing massive tariffs among themselves, while punishing emerging economies. However, as we shall see next, technological leaps also add up to the weakening of international trade in a substantial way.

\footnotetext{
${ }^{87}$ Robert Kagan, “The United States and Russia aren't Allies. But Trump and Putin are", NPR, 17 July 2018, https://www.npr.org/2018/07/17/629598855/opinion-the-unitedstates-and-russia-arent-allies-but-trump-and-putin-are?. Accessed 18 July 2018.

${ }^{88}$ David Brooks, op. cit.

${ }^{89}$ Bruno Le Maire, “"Trade war a reality' French Finance minister warns”, BBC News, 22 July 2018.
} 